\title{
Geophysical and geochemical constraints on crustal accretion at the very-slow spreading Mohns Ridge
}

\author{
Frauke Klingelhöler and Louis Céli \\ IFREMER, Plouzané, France \\ Robert S. Whitie \\ Bullard Laboratories, Cambridge, UK
}

\begin{abstract}
The composition of upper mantle and lower crustial material at very-slow spreading centers cannot be reliably determined by seismic studies alone. Since the range of $\mathrm{P}$-wave velocities for serpentinized peridotites and gabbros overlap, additional information provided by the major: and rare earth element (REL) content of the basalts is useful to constrain inter rretations of seismic datia. Refraction seismic dalia from lihe veryslow spreading ( $16 \mathrm{~mm} / \mathrm{a}$, full rate) Mohns Ridge in the Norwegian-Greenland Sea yields a highly variable thin crust of $4.0 \pm 0.5 \mathrm{~km}$ thickness. Analysis of S-waves suggests that Layer 3 is composed primarily of gabbro containing at most a small percentage $(<20 \%)$ of manthe material. The Nas content of Mohns Ridge basalts suggests a magmatic crustal thickmess of $4-5 \mathrm{~km}$. Inversion of the REE concentrations yields a melt thickness of $\sim 5 \mathrm{~km}$. This agreement between seismic and geochemical data suggests that neither large quantities of mantle material are found in the lower crust nor is a. large volume of basaltic magna frozen in the upper mantle.
\end{abstract}

\section{Introduction}

Some of the main questions regarding crustal accretion at very-slow spreading ridges concern the composition of the lower crust and upper mantle. Combination of geological field observations, petrological data and geophysical evidence (mostly seismic and gravity data) indicates that at very-slow spreading rates the lower crust may not comprise solely magmatic gabbros, but may consist at least partially of serpentinized periclotite [Cannat, 1993]. The upper mantle might be highly serpentinized [Francis, 1981] or: contain magma that has been frozen and trapped due to increased cooling resulting from the very slow spreading (Cannat [1996] suggests that the amount of frozen melt in the upper: mantle may be as high as $25 \%$ down to $10-20 \mathrm{~km}$ depth).

For spreading rates lower than $20 \mathrm{~mm} / \mathrm{a}$, numerical models predict that the crustal thickness decreases with spreading rate [Bown and While, 1994]. This is confirmed by the few seismic refraction studies conducted to date at very slow $(<20 \mathrm{~mm} / \mathrm{a}$ ) spreading centers, all of which have reported reduced crustal thicknesses (e.g. Jackson et al. [1982] in the Arctic Ocean; Muller et al. [1997] on the South-West Indian Ridge). Since

Copyright 2000 by the American Geophysical Union.

Paper number 1999GL008398.

0094-8276/00/1999GL008398\$05.00 correlations between seismic velocities and lithology of the crust, are non-unique, modeling of geochenical dati. can provide insight into the crustal composition of midocean ridges.

Because the temperature and flow regime of the manthe influence the extent of partial melting [McKenzie and O'Nions, 1991; Klein and Langmuir, 1987], variations in mid-ocean ridge basalt (MORB) chemistry and crustal thickness should be correlated [Klein and Langmuir, 1987; Niu, 1997]. Consequently, the use of geochenical data may provide valuable constraints on the melting enviromment and melt thickness [White et al. 1992; Muller et al., 1997]. In this paper we discuss geophysical and geochemical data from the Mohms Ridge, a very-slow, oblique spreading ridge in the NorwegianGreenland Sea (see Figure 1) [Géli el al, 1994].

\section{Seismic results}

Modeling [Zelt and Smith, 1992] of the seismic refraction data from Mohns Ridge yields a thin crust of

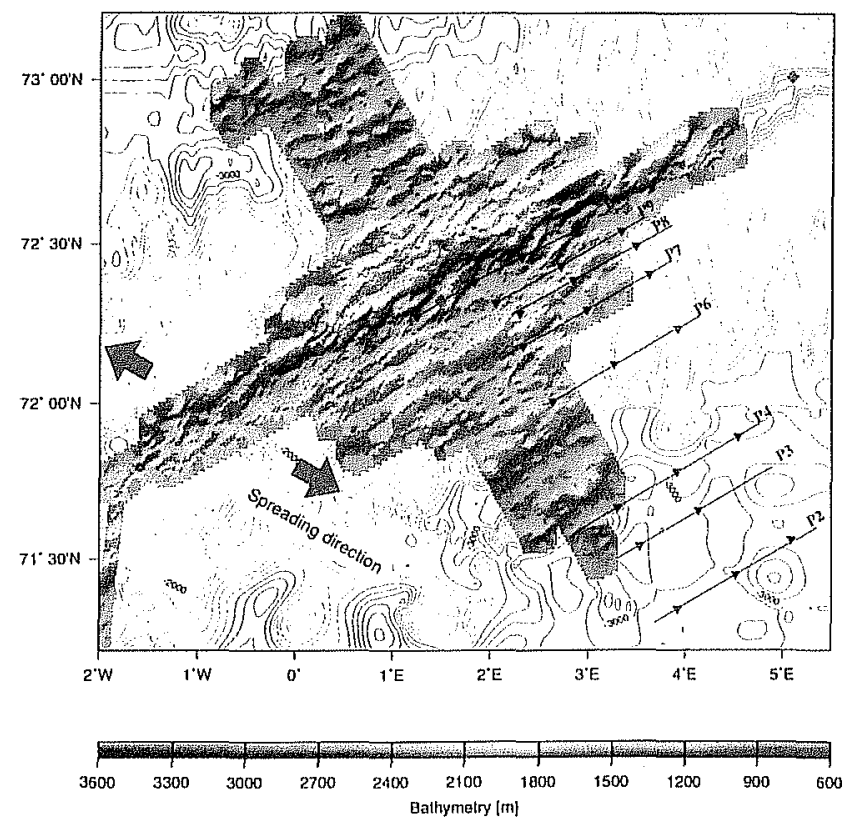

Figure 1. Study area at the very-slow spreading Mohns ridge in the Norwegian-Greenland Sea at $72^{\circ} \mathrm{N}$. Seafloor relief from SeaBeam data acquired during the cruise. Refraction profiles and OBH positions are indicated by black lines and inverted triangles, sample locations from $\mathrm{F} / \mathrm{S}$ Meteor by stars and from R/V Endeavor by diamonds. 

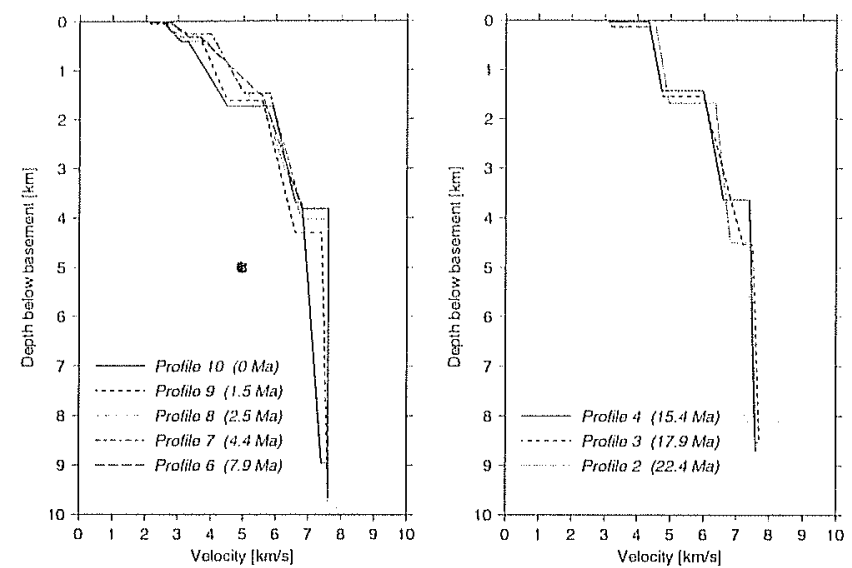

Figure 2. Velocity-depth relationship averaged for gradients and layer thicknesses. Shaded gray areas from While et al. [1992] for Atlantic crust 0-127 and 0-7 Ma.

$4.0 \pm 0.5 \mathrm{~km}$ thickness, with a very thin Layer 3 and nearly normal thickness Layers $2 \mathrm{~A}$ and $2 \mathrm{~B}$ [Kilingelhöer et al., in press]. Variations of crustal thickness are accomodated by changes in seismic Layer 3, which thickens below topographic highs and thins below local basins. Figure 2 shows velocity-depth curves averaged for gradients and layer thickness from all profiles.

The high quality $S$-wave arrivals on the off-ridge profiles yield a Poisson's ratio of 0.28 for Layer 3 . Compared to experimental measurements of gabbros and serpentinized peridotites from the MARK area. [Miller and Christensen, 1997], and from the compilation of Carlson and Miller [1997], the values for Mohns Ridge fall into the gabbroic field (see Figure 3). However, pure gabbros and peridotites with $10-20 \%$ serpentinite

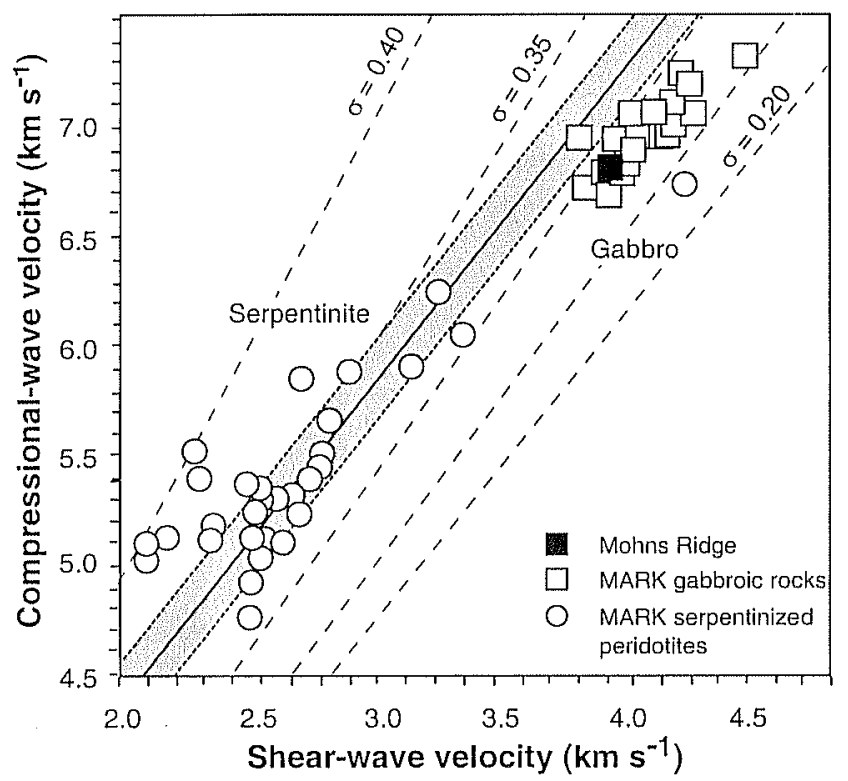

Figure 3. Vp, Vs and Poisson ratio measured on gabbros and serpentinized peridotites from the MARK area and as found from S-wave modeling for Mohns Ridge for comparison. Redrawn after Miller and Christensen [1997]. Shaded line shows serpentinite trend reported by Carlson and Miller [1997]. can exhibit similar Poisson ratios al $P$-wave velocities of $0.1-7.2 \mathrm{~km} / \mathrm{s}$ [Horen et al., 1996]. From refraction modeling one can say that Layer 3 consists of gabbro with at most $10-30 \%$ serpentine

The upper mantle velocity is low, around $7.4-7.8 \mathrm{~km} / \mathrm{s}$, with the lowest values below the spreading axis. Low mantile velocities are found lihroughout the northern North Atantic [Barton and White, 1997; Navin et al, 1.998], and may be related to the Iceland mantile plume. A separalte plume has been proposed beneath Jan Mayen [Schilling et al., 1983], which potentially could explain the low mantle velocities beneath the Molns Ridge. However, this is unlikely since there is no plume track and no petrological evidence for excess temperatures underneath Jan Mayen, and a comparison of crustal thickness with a numerical model [Bown and White, 1994] requires no anomalously high mantie temperatures [Klingelhofer et al., in press]. It appears more likely that the Jan Mayen melting comes from volatilerich mantle due to the influence of a nearby fracture zone and a propagating rift [Haase et al., 1996]. Two other possible causes for the anomalously low mantle velocity have been proposed: i) melt frozen in veins in the mantle as suggested by observations from ophiolites [Coulton et al., 1995; Cannat, 1996]; and ii) serpentinization of the upper mantle through fluids crossing the thin crust in faults and entering the upper mantle [Francis, 1981]. We use geochemical evidence to address these possibilities.

\section{Geochemical results}

We use published geochemical datasets from dredges on the Mohns Ridge obtained from two cruises: the F/S Meteor [Haase et al., 1996] and the R/V Endeavor [Neumann and Schilling, 1984] (dredge sites see Fig. 1).

As $\mathrm{Na}$ is a moderately incompatible element it can be used as an indicator of the degree of melting. A high $\mathrm{Na}$

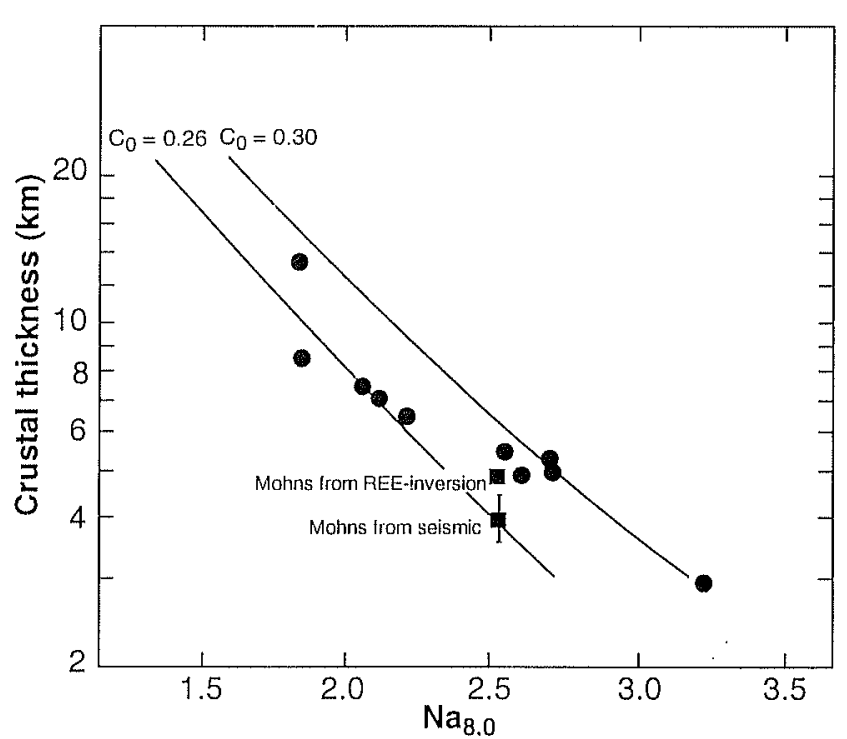

Figure 4. Seismically determined crustal thickness versus $\mathrm{Na}_{8,0}$ for different mid-ocean ridges. Curves are theoretical fractional melting calculations for source abundance of $\mathrm{Na}_{2} \mathrm{O}=0.30 \mathrm{wt} \%$ (primitive mantle) and $\mathrm{Na}_{2} \mathrm{O}=0.26$ wt\% (slightly depleted mantle). Redrawn after Klein and Langmuir [1987]. 
content indicaties a low degree of melting. To correct the geochemical datia for fractionation to $\mathrm{MgO}=8 \mathrm{wt} \%$, the Nas content is calculated from the $\mathrm{Na}_{2} \mathrm{O}$ content with the formula ( $\mathrm{Na}_{8}=\mathrm{Na}_{2} 0+-0.06 \mathrm{MgO}-0.48$ ) derived from the Mohns Ridge dalia [Haase et al., 1996]. Both dala sets have a $\mathrm{Nas}$ content of $2.64 \mathrm{wl} \%$. Comparison with empirical correlations of crustal thickness versus $\mathrm{Na}_{8}$ from a global dataset (see Figure 4) indicates that the $2.64 \mathrm{wt} \%$ concentration measured on the Mohns Ridge samples corresponds to a crustal thickness of $4 \mathrm{~km}$ if the mantile source $\mathrm{Na}_{2} \mathrm{O}$ content is 0.26 , which is appropr.ate for depleted mantle [Klein and Langmuir, 1987]. If the Molnns Ridge mantile is more enriched, as appears to be the case from Sm-Nd isotopic measurements [Hatase et al., 1996], then the parent mantle $\mathrm{Na}_{2} \mathrm{O}$ concentration would be higher and a crustal thickness of about $5 \mathrm{~km}$ would be inferred.

We also use the REE concentrations to infer the total amount of melting in the mantle [Mclienzie and O'Nions, 1991; White et al., 1992]. We use a depth for' the top of the melting column of $25 \mathrm{~km}$, which is appropriate for mantle conductively cooled beneath a veryslow spreading center [Bown and White, 1974]. Spinel is allowed to be stable to depths of $80 \mathrm{~km}$, and garnet is stable only at depths below $60 \mathrm{~km}$. We allow the calculation of melting to extend as deep as $100 \mathrm{~km}$, although only at depths shallower than $80 \mathrm{~km}$ does the partial melting exceed $1 \%$, which is consistent with the onset of melting in normal temperature mantle not influenced by mantle plumes [White et al., 1992]. The REE inversion requires the mantle composition to be defined. The Mohns Ridge basalts are enriched in light, REE and other incompatible elements (Figure 5). We calculate the ratio of enriched to normal MORB-source mantle by using the observed average $\epsilon_{\mathrm{Nd}}$ of 7.0 measured on the Mohns Ridge basalts [Haase et al., 1996], although we also show below the range of fits that would result if the mantle source were either of the end-members of depleted or enriched mantle.

Taking data from the two cruises separately, the Haase et al. [1996] REE concentrations (Fig. 5a) are, on average, about $30 \%$ lower than the Neumann and Schilling [1984] REE concentrations (Fig. 5b). Separate $R E E$ inversions for these two datasets yield very different melt thicknesses of $6.6 \mathrm{~km}$ for the Haase et al. [1996] data and $4.5 \mathrm{~km}$ for the Neumann and Schilling [1984] data. However, the two sets of samples appear to have undergone different amounts of fractionation, and after the measured REE concentrations for each sample have been corrected for: fractionation using the observed Fe and Mg contents [McKenzie and O'Nions, 1991], the REE distributions for samples from the two cruises are indistinguishable. Melt thicknesses from separate REE inversions of the corrected data are 5.3 and $4.8 \mathrm{~km}$, while inversion of the combined REE dataset yields a thickness of $5.0 \mathrm{~km}$ (solid line, Fig. $5 \mathrm{c}$ ).

REE inversion of the combined dataset, using first depleted MORB source mantle, and then primitive manthe give melt thicknesses of 4.5 and $5.9 \mathrm{~km}$ respectively (broken lines, Fig. 5c). The REE fit for the depleted source is worse than the best-fit with $\epsilon_{\mathrm{Nd}}=7.0$, but that for a primitive source is much betiter. However, because the observed $\epsilon_{\mathrm{Nd}}$ average 7.0 , and because there is no other evidence for a mantle plume in this area of the Mohns Ridge, we suggest that the light REE enrichment is due to contamination by small melt fraction wet melts [Haase et al., 1996]. The appropriate melt

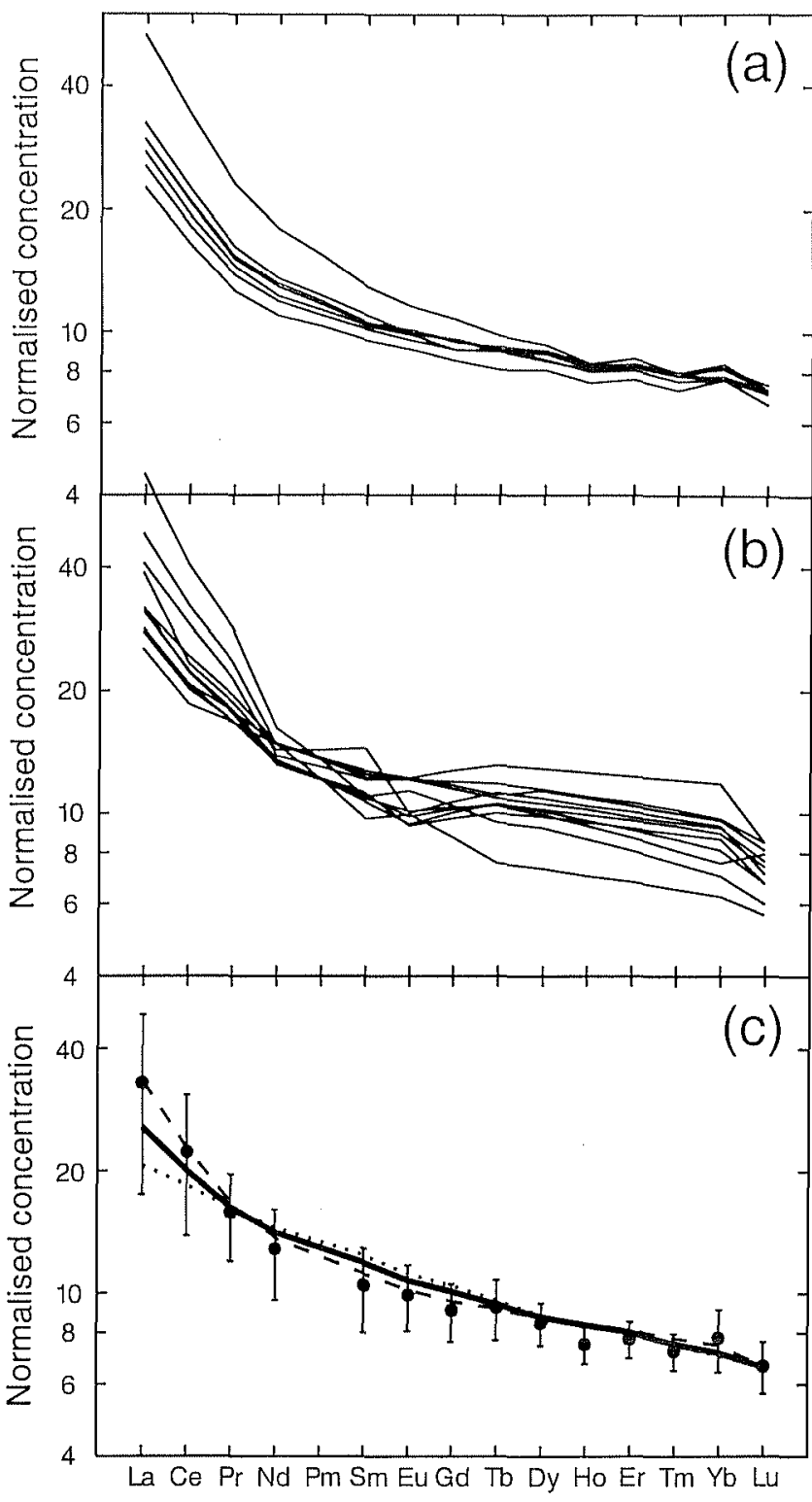

Figure 5. Element concentration ratios with respect to depleted mantle from McKenzie and O'Nions [1991]. (a) Raw data from Haase et al. [1996]; (b) Raw data from Neumann and Schilling [1984]; (c) Inversion of combined REE dataset after correction of REE concentrations for fractionation. Filled circles are averages and vertical bars show range of observed values. Solid line is best-fit REE inversion with $\epsilon_{\mathrm{Nd}}$ of 7.0 , giving melt thickness of $5.0 \mathrm{~km}$ (see Table 1). Long dashed line is inversion assuming primitive mantle and dotted line assuming depleted MORB-source mantle.

thickness to use is thus $5.0 \mathrm{~km}$, derived assuming dominantly depleted parent mantle with $\epsilon_{\mathrm{Nd}}=7.0$ beneath the Mohns Ridge.

\section{Discussion and conclusions}

The crustal thickness at Mohns Ridge inferred from geochemical analyses $(4-5 \mathrm{~km})$ is similar to the crustal thickness found from seismic refraction data (4.0 \pm 0.5 $\mathrm{km})$. A systematic discrepancy between the results of 
both methods on the order of $0.5-1 \mathrm{~km}$ is observed worldwide, but is on the order of the error margins inherent in each method and thus not considered to be significant [White et al., 1992]. Analysis of S-waves indicates that Layer 3 is composed of gabbros conlaining at most a small percentage (10-30\%) of serpentinized pertotite. These amounts (melt missing seismic layer 3 and difference between melt thickness and crustal thickness) will lead to at most $10 \%$ of frozen, trapped melt remaining in the uppermost $15 \mathrm{~km}$ of the mantle at, Mohns Ridge, a proportion which is insufficient to explain the low mantle velocities. We thus exclude the possibility of having a significant proportion of frozen magma in the upper mantle (even if the obliqueness of spreading is expected to enhance cooling effects resulting from very slow spreading). Instead, we favor the serpentinization of the upper mantle though fluids crossing the thin crust along faults to explain the anomalously low mantle velocities [Francis, 1981]. This suggests that neither large quantities of mantle material are found in the lower crust, as has been reported for the northern Mid-Ablantic Ridge [Cannat, 1993], nor is frozen basaltic magma required in the upper manthe. The seismic Moho corresponds approximately to the boundary between extrusives and mantle material, and is not likely to be an alteration front.

Acknowledgments. The GMT [Wessel and Smith, 1995] software was used for figures and INVMEL software [Mclienzie and O'Nions, 1991] for inversion of the REE. We thank L. Dosso, T. A. Minshull and three anonymons reviewers for valuable comments on the original manuscript. Funding was provided by the European Community through a. Marie-Curie fellowship for F. Klingelhöfer.

\section{References}

Barton, A. J., and R. S. White, Crustal structure of the Edoras Bank continental margin and mantle thermal anomalies beneath the North Atlantic, J. Geophys. Res., 102, 3109-3129, 1997.

Bown, J. W., and R. S. White, Variation with spreading rate of oceanic crustal thickness and geochemistry, Earth Planet. Sci. Lett., 19, 25-36, 1994.

Cannat, M., Emplacement of mantle rocks in the seafloor at mid-ocean ridges, J. Geophys. Res., 98(B3), 4163-4172, 1993.

Cannat, M., How thick is the magmatic crust at slow spreading oceanic ridges?, J. Geophys. Res., 101(B2), 2847$2857,1996$.

Carlson, R. L., and D. J. Miller, A new assessment of the abundance of serpentinite in the oceanic crust, Geophys. Res. Lett., 24, 457-460, 1997.

Coulton, A. J., G. D. Harper, and D. S. O'Hanley, Oceanic versus emplacement age serpentinization in the Josephine ophiolite: Implications for the nature of the Moho at intermediale and slow spreading ridges, J. Geophys. Res., 100(B11), 22,245-22,260, 1995.

Francis, T. J. G., Serpentinization faults and their role in the tectonics of slow spreading ridges, J. Geophys. Res., 86, 11,616-11,622, 1981.

Géli, L., V. Renard and C. Rommevaux, Ocean crust formation processes at very slow spreading centers: A model for the Mohns Ridge, near $72^{\circ} \mathrm{N}$, based on magnetic, gravity, and seismic data, J. Geophys. Res., 99, (B2), 2995-3013, 1994 .
Haase, K. M., C. W. Devey, D. F. Mertz, P. Stoffers, and D. Garbe-Schoenberg, Geochemistry of lavas from Mohns Ridge, Norwegian-Greenland Sea: implications for melting conditions and magma sources near Jan Mayen, Contrib. Mineral. Pelrol., 123, 223-237, 1996.

Horen, H., M. Zamora, and G. Dubuisson, Seismic waves velocities and anisotropy in serpentinized peridotites from Xigaze ophiolite: Abundance of serpentine in slow spreading lidge, Geophys. Res. Lett., 23(1), 9-12, 1996.

Jackson, H. R., Reid, I., and R. IK. H. Falconer, Crustal structure near the Arctic mid-ocean ridge, J. Geophys. Res., 87, 1773-1783, 1982.

Klein, E. M., and C. H. Langmuir, Global correlations of ocean ridge basalt chemistry with axial depth and crustal thickness, J. Geophys. Res., 92 (B8), 8089-8115, 1987.

Klingelhöfer, F., Géli, L., and Matias, L., Crustal structure of a super-slow spreading centre: a seismic refraction study of Mohns Ridge, $72^{\circ} \mathrm{N}$, in press Geophys. J. Int., 2000.

McKenzie, D., and R. K. O'Nions, Parlial melt distributions from inversion of rare earth element concentrations, $J$. Petrol., 32, 1021-1.091, 1991.

Miller, D. J., and N. I. Christensen, Seismic velocities of lower crustal and upper mantle rocks from the slow spreading Mid-Atlantic Ridge, south of the Kane Transform Zone (MARK), Proceedings of the Ocean Drilling Program, Scientific Results, edited by Karson, J. A., Canna.t, M., Miller, D. J. \& Elthon, D., 437-453, 1997.

Muller, M. R., C. J. Robinson, T. A. Minshull, R. S. White and M. J. Bickle, Thin crust beneath ocean drilling program borehole $735 \mathrm{~B}$ at the southwest Indian Ridge?, Earth Planet. Sci. Lett., 117, 295-317, 1997.

Navin, D. A., C. Peirce, and M. C. Sinha, RAMESSES experiment - II. Evidence for accumulated melt beneath a slow-spreading ridge from wide-angle refraction and multichannel reflection seismic profiles, Geophys. J. Int., 135, $746-772,1998$.

Neumann, E.-R., and J.-G. Schilling, Petrology of basalts from the Mohns-Knipovich Ridge; the NorwegianGreenland Sea, Contrib. Mineral. Petrol., 85, 209-223, 1984.

Niu, Y., and R. Hekinian, Spreading rate dependence of the extent of melting beneath ocean ridges, Nature, 335, 326$329,1997$.

Schilling, D. T., Zajac, M., Evans, T., Johnston, T., White, W., Devine, J. D., and R. Kingsley, Petrologic and geochemical variations along the Mid-Atlantic Ridge from $29^{\circ} \mathrm{N}$ to $73^{\circ} \mathrm{N}, A m$. J. Sci. $283,510-586,1983$.

Wessel, P., and W. H. F. Smith, A new version of the Generic Mapping tools (GMT), EOS Trans. AGU, 76, 329, 1995.

White, R. S., D. McKenzie, and R. K. O'Nions, Oceanic crustal thickness from seismic measurements and rare earth element inversions, J. Geophys. Res., 97(B13), 19,683-19,715, 1992.

Zelt, C. A., and R. B. Smith, Seismic travel time inversion for 2-D crustal velocity structure, Geophys. J. Int., 108 , 16-34, 1.992.

F. Klingelhöfer and L. Géli, IFREMER, DRO GM, B. P. 70, F-29280 Plouzané, France (e-mail: frauke.klingelhoefer@ifremer.fr)

R. S. White, Bullard Laboratories, Madingley Road, Cambriclge, CB3 0EZ, UK (e-mail: rwhite@esc.cam.ac.uk)

(Received July 1, 1999; revised October 25, 1999; accepted February 11, 2000.) 